\title{
Ketjun toimivuus tiedonkulun näkökulmasta Tapaustutkimus kahdesta luomuketjusta
}

\author{
Marja-Riitta Kottila ${ }^{1)}$, Päivi Rönni' ${ }^{2)}$ \\ ${ }^{1)}$ Helsingin yliopisto, Agroekologia,00014 Helsingin yliopisto, marja-riitta.kottila@helsinki.fi \\ ${ }^{2)}$ Helsingin yliopisto, Markkinointi,00014 Helsingin yliopisto, paivi.ronni@helsinki.fi
}

\section{Tiivistelmä}

Ristiriita kuluttajien kiinnostuksen ja luomutuotteiden markkinaosuuden välillä sekä ketjun toimijoiden kokemat ongelmat herättävät kysymyksiä ketjun toimivuudesta. Niihin vastaaminen edellyttää tietoa luomuketjun toimijoiden välisestä vuorovaikutuksesta.

Tutkimuksen tavoitteena oli tutkia tiedonkulkua luomuketjussa ja sen vaikutusta luomuketjun toimivuuteen. Tutkimuskysymykset olivat:

- Mitä ja miten tieto kulkee luomun tarjontaketjussa?

- Kuinka luomuketjun toimijat kokevat toimijoiden välisen vuorovaikutuksen ja ketjun tietovirran?

- $\quad$ Mitä tietoa toimijat tarvitsevat ja keneltä ketjun toimivuuden parantamiseksi?

Tutkimuksen keskeinen käsite on tarjontaketju. Tarjontaketju koostuu peräkkäisistä toimijoista, jotka pyrkivät toiminnallaan tuottamaan arvoa asiakkaalle. Ketjun toimijoita sitovat yhteen organisaatioiden rajat ylittävät tuote- ja informaatiovirrat. Tarjontaketjujen hallinnan avulla pyritään parantamaan ketjun kilpailukykyä yhdistämällä ketjun keskeisiä prosesseja. Tieto ja sen sujuva kulku on keskeistä ketjun hallinnassa. Luomuketju yhdistetään ns. vaihtoehtoisiin ketjuihin, joiden keskeinen piirre on toimijoiden välisiin suhteisiin ja/tai ketjussa liikkuvaan informaatioon perustuva lisäarvo. Ostamisen helppouden vuoksi suurin osa luomutuotteista myydään päivittäistavarakaupan kautta, mikä sulauttaa luomuketjun osaksi tavanomaista ketjua ja asettaa haasteita tiedonkululle. Tutkimusmenetelmä oli tapaustutkimus, jossa tutkittiin kahta, tuotteiltaan, pituudeltaan ja työnjaoltaan erilaista luomuketjua.

Tulosten mukaan tuotteen kulkuun liittyvä tieto kulki pääsääntöisesti hyvin, ja toimijat olivat muutamaa poikkeusta lukuun ottamatta siihen tyytyväisiä. Tiedonkulun ongelmat ja tyytymättömyys liittyivät erityisesti myyntitietoon, luomua koskevan tiedon huonoon hallintaan ja vähäiseen vuorovaikutukseen kuluttajien kanssa. Sekä kuluttajille kohdistettu tieto luomutuotteista ja niiden lisäarvosta sekä informaatio kuluttajien tarpeista luomutuotteiden osalta oli vähäistä. Toimijoiden välinen vuorovaikutus oli pääsääntöisesti kahdenvälistä, ei koko ketjun kattavaa.

Ketjujen väliset erot tiedonkulussa johtuivat tuotteen erilaisuudesta ja toimijoiden välisistä suhteista. Vain osa tiedonkulkuun liittyvistä ongelmista liittyi luomuun. Osa johtui elintarvikeketjun vallitsevista toimintatavoista ja osa luomuun erikoistuneiden yritysten pienestä koosta sekä niiden asemasta ketjussa. Tutkimuksen mukaan luomuketjun toimivuutta voidaan parantaa tiedonkulkua parantamalla. Tämä edellyttää sekä toimijoidenvälisen tiedonvaihdon ja vuorovaikutuksen parantamista että tiedonlaadun parantamista.

Asiasanat: Luomu, kysyntä/tarjontaketju, toimijoiden välinen tiedonvaihto, toimijoiden väliset suhteet 


\section{Johdanto}

Kiinnostus luonnonmukaisesti tuotettuihin elintarvikkeisiin on kasvanut Suomessa ja muualla länsimaissa viimeisen vuosikymmenen kuluessa. Luomutuotteiden markkinaosuudet ovat kuitenkin selvästi pienemmät kuin kuluttajien tutkimuksissa ilmaisema kiinnostus luomutuotteita kohtaan(Finfood 2004b, Schmid et al. 2004, Wier and Calverley 2002). Sekä kuluttajien luomutuotteiden käytön että ketjun toimijoiden luomutarjonnan lisäämisen tiellä on todettu olevan esteitä (Baecke et al. 2002, Finfood 2004a, Finfood 2004b, Franks 2003, Hamm and Gronefeld 2004, Wycherley 2002). Aikaisempi tutkimus on keskittynyt pääosin yhden tai muutaman toimijaryhmän, kuten viljelijöiden tai kuluttajien, teollisuuden tai kaupan, tarkasteluun. Tämä tutkimus pyrkii läpivalaisemaan luomun kysyntä/tarjontaketjua kokonaisuutena tutkimalla ketjun toimijoiden välistä vuorovaikutusta ja tiedonkulkua.

\section{Tutkimuksen tavoite}

Tutkimuksen tavoitteena oli ymmärtää luomuketjun toimintaa ja erityisesti toimijoiden vuorovaikutuksen ja tiedonkulun vaikutusta ketjun toimivuuteen. Tutkimuskysymykset olivat:

- $\quad$ Mitä ja miten tieto kulkee luomun tarjontaketjussa?

- Kuinka luomuketjun toimijat kokevat ketjun toimivuuden ja tiedonkulun toimivuuden?

- $\quad$ Mitä tietoa toimijat tarvitsevat ja keneltä ketjun toimivuuden parantamiseksi?

\section{Kysyntä/tarjontaketjun käsite}

Tutkimuksen keskeinen käsite on kysyntä/tarjontaketju, josta tässä käytetään nimitystä ketju. Ketju koostuu itsenäisistä, peräkkäisistä toimijoista, jotka pyrkivät toiminnallaan tuottamaan arvoa yhteiselle loppuasiakkaalle. Ketjun toimijat ovat itsenäisiä organisaatioita, joilla kullakin on omat arvonsa, tavoitteensa ja voimavaransa. Toimijat ovat riippuvaisia toisistaan omien tavoitteidensa ja loppuasiakkaalle yhteisesti tuotettavan arvon saavuttamiseksi. Ketjun lävitse kulkee erilaisia ja erisuuntaisia virtoja, joista tämän tutkimuksen kannalta keskeisimmät ovat molempiin suuntiin kulkeva tietovirta sekä alkutuotannosta loppuasiakkaalle kulkeva tuotevirta. (Coughlan et al. 2001, Roosenbloom 2004).

Tarjontaketjujen hallinnan avulla pyritään parantamaan ketjun kilpailukykyä yhdistämällä ketjun toimijoiden erillisiä prosesseja ketjun kattaviksi prosesseiksi. Ketjun hallinnan myötä pyritään vähentämään ketjun kokonaiskustannuksia ja lisäämään arvoa asiakkaalle. Elintarvikeketjujen hallintaan kehitettyä mallia kutsutaan termillä ECR (= Efficient consumer response). Ketjun hallinnan keskeinen väline on tieto ja sen joustava kulku ketjun toimijoiden välillä. (Alvarado and Kotzab 2001, Fearne et al. 2001, Finne ja Kokkonen 1998, Lambert et al. 1998, Seppälä 2003, Tarpila et al. 1999, Vorst van der 2000).

Luomuketjua tarkastellaan usein ns. vaihtoehtoisena ketjuna, jonka keskeinen piirre on toimijoiden välisiin suoriin suhteisiin ja/tai ketjussa liikkuvaan tietoon tuotteiden alkuperästä ja/tai tuotantotavasta perustuva lisäarvo (Marsden et al. 2000)Vaikka päivittäistavaraketjuja ei pidetä monissa maissa sopivina luomutuotteiden myyntikanavina, ovat luomumarkkinan kasvu ja kuluttajien ostotottumukset johtaneet siihen, että suurin osa luomutuotteista myydään nykyisin Suomessa ja muualla Euroopassa päivittäistavarakaupan kautta (Bähr et al. 2004). Näin volyymiltään pieni luomuketju yhdistyy osaksi tavanomaista elintarvikeketjua.

\section{Aineisto ja menetelmät}

Tutkimusmenetelmä oli tapaustutkimus, jossa tutkittiin kahta, tuotteiltaan, pituudeltaan ja työnjaoltaan erilaista luomuketjua. Ketjussa 1 kulkee teollinen tuoretuote ja ketjussa 2 teollinen viljatuote. Ketjut kulkevat samojen päivittäistavarakaupparyhmien kautta. Molemmissa ketjuissa luomuvalmistaja on pelkästään luomutuotteita valmistava pienyritys. Ketjussa 1 pienyritys toimii alihankkijana isolle yritykselle, joka vastaa tuotteiden myynnistä ja markkinoinnista. Ketjun 2 valmistaja myy tuotteensa omalla tuotemerkillä toiselle kaupparyhmälle ja kaupan merkillä toiselle kaupparyhmälle. Luomuvalmistajia ja viljelijöitä lukuun ottamatta luomun osuus oli ketjuissa vähäinen (kuva 1). Ketjut kuvattiin luomuvalmistajan näkökulmasta seuraamalla valittujen tuotteiden matkaa raaka-aineista keskeisten toimijoiden kautta vähittäiskauppaan. Tutkimuksessa tarkasteltiin vuorovaikutusta neljän prosessissa, jotka olivat valikoima-, tilaus/toimitus-, promootio- ja tuotelanseerausprosessi.

Tutkimusaineisto kerättiin teemahaastatteluin. Ketjun toimijoiden keskuudessa viljelijöistä 
vähittäiskauppaan tehtiin yhteensä 27 haastattelua 15.11.2004 - 15.3.2005 välisenä aikana. Näitä täydennettiin kolmella sidosryhmähaastattelulla, jotka toteutettiin elo - syyskuussa 2005. Haastateltavat valittiin siten, että he edustivat tutkittuja prosesseja ja vastasivat kyseiseen tuotteeseen liittyvistä toiminnoista. Haastattelut nauhoitettiin ja litteroitiin. Haastattelujen lisäksi aineistona käytettiin yritysten internetsivuja, toimintakertomuksia ja haastattelujen yhteydessä luovutettua aineistoa. Yksittäiset haastattelut ja muu aineisto yhdistettiin toimijakohtaisiksi raporteiksi, jotka lähetettiin kullekin ketjun toimijalle. Raporttien pohjalta tehtiin ketjukohtaiset analyysit yhdistämällä ja vertailemalla eri toimijoiden näkemyksiä. Lopuksi vertailtiin kahta ketjua keskenään. Haastatelluille järjestettiin syyskuussa 2005 kaupparyhmittäin kaksi 3,5 tunnin mittaista workshopia, johon osallistui toimijoita koko ketjun matkalta. Workshoppien osanottajien kommenttien ja täydennysten myötä alustavia tuloksia täsmennettiin.

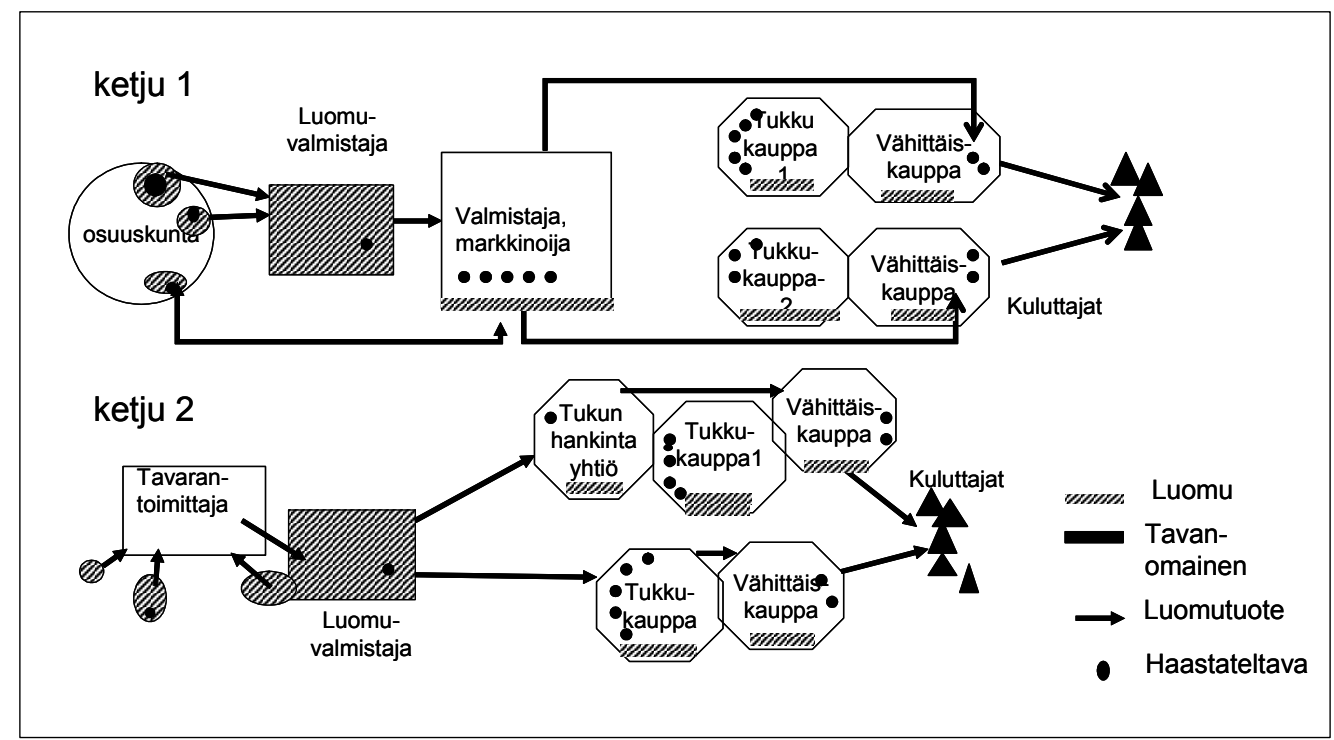

Kuva 1. Tutkittujen ketjujen rakenne ja haastateltavien sijoittuminen ketjuun

\section{Tulokset ja tulosten tarkastelu}

Mitä ja miten tieto kulkee ketjussa?

Tutkimukseen valituista neljästä prosessista löydettiin vain kolme, sillä kummassakin ketjussa tuotteiden promootiot olivat niin satunnaisia, että varsinaista prosessia ei voitu erottaa (kuva 2). Promootioiden vähäisyys liittyi joko yrityksen vähäisiin resursseihin tai luomun vähäiseen ja/tai ristiriitaiseen strategiseen asemaan yrityksessä.

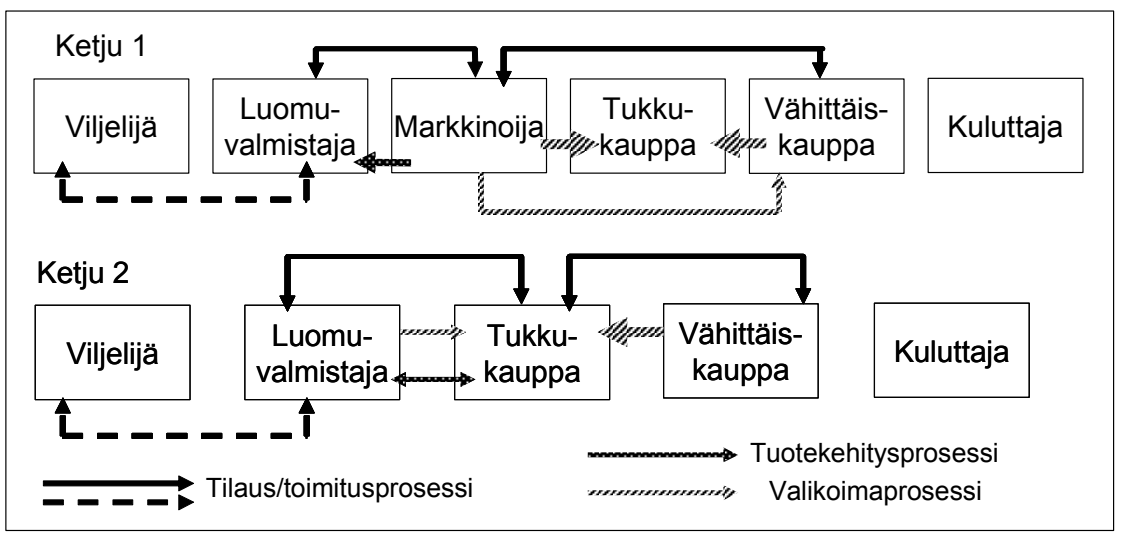

Kuva 2. Vuorovaikutus tutkituissa prosesseissa

Tutkituissa prosesseissa ketjun lähimmät toimijat olivat vuorovaikutuksessa keskenään.Prosessit eivät nivoneet kuluttajia osaksi ketjua ja viljelijöiden osalta vuorovaikutus liittyi pääosin tuotantosopimuksiin ja tuotteen toimittamiseen. Tukkukaupalla valikoiman muodostajana oli keskeinen rooli vuorovaikutuksessa, koska kyseiset tuotteet kuuluivat kaupparyhmien ketjuvalikoimiin. Tukku oli kiinteässä 
vuorovaikutuksessa sekä vähittäiskauppojen että tavarantoimittajien kanssa. Tuotekehitysprosessissa ketjut erosivat selvästi toisistaan. Ketjun 2 tuotekehitysprosessi oli vuorovaikutteinen valmistajan ja tukun välillä toisin kuin ketjun 1, jossa markkinoija hoiti tuotteiden kehityksen ja opasti valmistavan yrityksen niiden prosessointiin.

Tarkemman analyysin kohteeksi valittiin tiedot, joita tarvittiin useassa prosessissa. Näitä olivat myyntitieto, kuluttajia koskeva tieto, tuotetieto sekä luomun lisäarvosta kertova tieto. Viimeksi mainituksi tiedoksi määritettiin tieto, joka koskee luomun tavanomaisesta eroavasta tuotantotavasta johtuvia ominaisuuksia ja/tai niiden vaikutuksia. Kuvat 3 ja 4 kuvaavat kenellä ketjun toimijoista oli kyseistä tietoa ja miten tieto liikkui ketjussa (kuvat 3-4).

Kuva 3. Myyntitieto ja sen kulku tutkituissa ketjuissa

\begin{tabular}{|c|c|c|c|c|c|}
\hline Myyntitieto & Viljelijä & $\begin{array}{l}\text { Valmis- } \\
\text { taja }\end{array}$ & Markkinoija & $\begin{array}{l}\text { Tukku- } \\
\text { kauppa }\end{array}$ & $\begin{array}{l}\text { Vähittäis- } \\
\text { kauppa }\end{array}$ \\
\hline $\begin{array}{l}\text { Luomutuotteen } \\
\text { myynti }\end{array}$ & & & 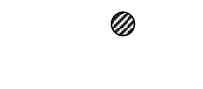 & & 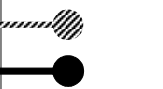 \\
\hline $\begin{array}{l}\text { Luomun } \\
\text { kokonaismyynti } \\
\text { (tuoteryhmässä/ } \\
\text { kaupparyhmässä) }\end{array}$ & & & 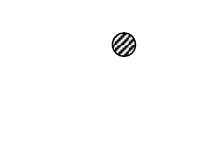 & 4 & mom \\
\hline $\begin{array}{l}\text { Kilpailijoiden } \\
\text { myynti }\end{array}$ & & & 0 & ? & \\
\hline $\begin{array}{l}\text { Luomun } \\
\text { kokonaismyynti }\end{array}$ & & & & & \\
\hline
\end{tabular}

Myyntitieto kulki ketjuissa huonosti. Myyntitietoa on erityisesti kaupalla, jossa se vähittäiskauppojen kautta kertyy tukkuliikkeelle. Tukku ei luovuttanut myyntitietoa ketjussa eteenpäin valmistajille. Ketjussa 1 markkinoijan tieto oli ulkopuoliselta toimijalta ostettua tietoa. Muut toimijat perustivat tietonsa menekistä omiin myynteihinsä ja toimitusmääriinsä. Kaupassa myyntitietoa seurataan tuotteittain ja tavararyhmittäin. Koska luomu hajautuu useiden tavararyhmien alle, kaupan tietotojärjestelmät olivat vasta kehittymässä siten, että luomutuotteiden kokonaismyyntiä tuoteryhmässä ja kaupparyhmässä voitiin seurata.

Kuva 4. Kuluttaja-, tuote- ja lisäarvotiedon kulku tutkituissa ketjuissa

\begin{tabular}{|l|c|c|c|c|c|}
\hline Tieto & $\begin{array}{l}\text { Viljeli- } \\
\text { jät }\end{array}$ & $\begin{array}{l}\text { Valmis- } \\
\text { taja }\end{array}$ & $\begin{array}{l}\text { Markki- } \\
\text { noija }\end{array}$ & $\begin{array}{l}\text { Tukku- } \\
\text { kauppa }\end{array}$ & $\begin{array}{l}\text { Vähittäis- } \\
\text { kauppa }\end{array}$ \\
\hline $\begin{array}{l}\text { Kuluttaja- } \\
\text { tieto }\end{array}$ & & & & 0 & 0 \\
\hline Tuotetieto & & & & & \\
\hline $\begin{array}{l}\text { Luomun lisä- } \\
\text { arvo tieto }\end{array}$ & 0 & 0 & & 0 & 0 \\
\hline
\end{tabular}

Kuluttajatietoa oli ketjussa melko vähän ja se oli ristiriitaista ja hajanaista. Eniten kuluttajatietoa oli vähittäiskaupoissa. Kuluttajien toiveita arvioitiin lähinnä myyntitietojen perusteella. Tuotetieto läpäisi ketjun parhaiten. Tuotetieto oli keskeinen valikoimaprosessissa ja myös vähittäiskaupassa korostettiin tuotetietoa. Luomun lisäarvotieto oli hyvin hajanaista ja sirpaleista, eikä se haastattelujen perusteella juurikaan kulkenut ketjussa. Luomun lisäarvosta toimijoilla oli myös hyvin erilaisia käsityksiä.

Kuinka luomuketjun toimijat kokevat ketjun ja tiedonkulun toimivuuden?

Ketjun toimijat vastasivat olevansa melko tyytyväisiä sekä ketjun toimintaan että tiedonkulun 
toimivuuteen ketjussa. Erityisesti kaupassa luomuketjun ei koettu eroavan tavanomaisista ketjuista. Ketjun toimivuudella haastateltavat tarkoittivat yleensä tuotteen fyysistä kulkua ketjussa. Vaikka ketjun toimijat kokivat ketjun yleisesti toimivan melko hyvin, luomutoiminnassa koettiin ongelmia. Ketjun toimivuudesta ilmaistujen käsitysten ja koettujen ongelmien pohjalta erottui aineistosta kolme ulottuvuutta ketjun toimivuudelle. Nämä ulottuvuudet nimettiin seuraavasti: tuotteen kulku, kysynnän ja tarjonnan tasapainottaminen ja toimijoiden yhteistyö (taulukko 1).

Tuotteen kulkuun liittyvä toimivuus arvioitiin ketjun 2 viljelijää lukuun ottamatta hyväksi tai melko hyväksi. Molemmissa ketjuissa kysynnän ja tarjonnan tasapainottaminen aiheutti ongelmia. Ketjun toimijoiden vuorovaikutus oli pääosin lähimpien toimijoiden keskeistä. Koko ketjun toiminnan tuntemus oli puutteellista ja käsitykset ketjussa etäämmällä olevien toimintatavoista perustuivat pääosin yleisiin käsityksiin, tai ketjun lähimmän toimijan välittämään tietoon. Viljelijöiden käsitykset ketjun toimivuudesta erosivat paljon ketjujen välillä, ja antavat viitteitä siihen, että tuoteryhmällä ja sen toimintakulttuurilla olisi vaikutusta käsityksiin. Tuoteryhmien erojen selvittäminen vaatisi kuitenkin lisää viljelijähaastatteluita. Toimivuuden ulottuvuuksista ainoastaan kysynnän ja tarjonnan kohtaaminen liittyi erityisesti luomutuotteisiin, koska luomutuotanto ja -valmistus edellyttävät erillään pitoa koko ketjussa. Ylimääräistä, tavanomaista kalliimpaa raaka-ainetta ei kannata käyttää tavanomaisiin tuotteisiin, eikä ylimääräistä kapasiteettia mielellään hyödynnetä valmistamalla tavanomaisia tuotteita erillään pidon aiheuttamien kustannusten vuoksi.

\begin{tabular}{|l|l|}
\hline Toimivuuden ulottuvuus & Toimivuuden arviointi \\
\hline Tuotteen kulku & Toimivuus melko hyvä \\
\hline $\begin{array}{l}\text { Kysynnän ja tarjonnan } \\
\text { kohtaaminen }\end{array}$ & $\begin{array}{l}\text { Toimivuudessa ongelmia: puuttuva kuluttajaimu, josta seurauksena } \\
\text { ylimäärä raaka-ainetta tai kapasiteetin vajaakäyttöä }\end{array}$ \\
\hline Toimijoiden yhteistyö & $\begin{array}{l}\text { Toimivuudessa ongelmia: Epäreilut toimintatavat, epäilyt hinnan } \\
\text { oikeudenmukaisuudesta, toimijoiden ristiriitaiset tavoitteet }\end{array}$ \\
\hline
\end{tabular}

Taulukko 1. Ketjun toimivuuden ulottuvuudet

\section{Mitä tietoa toimijat tarvitsevat ja keneltä ketjun toimivuuden parantamiseksi?}

Ketjun toimijoiden tiedontarpeet vaihtelivat ja liittyivät heidän roolinsa ketjussa (taulukko 2). Ketjun alkupäässä kaivattiin tuotantoon ja valmistamiseen liittyvän tiedon lisäksi tietoa kuluttajista ja myynneistä. Ketjun loppupäässä korostuivat menekin ennustamiseen, kilpailijoihin sekä tuotteisiin liittyvä tieto.

\begin{tabular}{|c|c|c|c|c|}
\hline Viljelijät & Luomuvalmistaja & Markkinoija & Tukkukauppa & Vähittäiskauppa \\
\hline $\begin{array}{l}\text { Kuluttajatieto } \\
\text { Tuotantoteknologia } \\
\text { Maatalous } \\
\text { politiikan } \\
\text { vaikutukset } \\
\text { Tukun ja kaupan } \\
\text { toimintaperiaatteet }\end{array}$ & \begin{tabular}{|l} 
Valikoimaluokat \\
Pitkän tähtäimen \\
suunnitelmat \\
Kuluttajien toiveet \\
Myynti eri kauppaketjuissa \\
Tukun varastotilanne
\end{tabular} & $\begin{array}{l}\text { Kuluttajien tarpeet } \\
\text { tuotekohtaisesti } \\
\text { Markkinan } \\
\text { kehittyminen } \\
\text { Ero tavanomaisesta } \\
\text { Säädökset, tuet } \\
\text { Myynti } \\
\text { Terveysvaikutukset }\end{array}$ & \begin{tabular}{|l} 
Tuotteen myynti- \\
potentiaali \\
Myynnin kehitys \\
Kilpailijoiden tilanne \\
Markkinan analysoinnin \\
mahdollistava tieto \\
Tuoteominaisuudet, hinta \\
Tavarantoimittajan \\
luotettavuus
\end{tabular} & \begin{tabular}{|l} 
Tuotteiden \\
valmistajat \\
Luomutuotteiden \\
ostajat \\
Tuotetiedot
\end{tabular} \\
\hline
\end{tabular}

Taulukko 2. Tiedonkulun toimivuus ja eri toimijoiden tarvitsema tieto.

Toimijat kokivat ongelmia molempiin suuntiin kulkevassa tietovirrassa (taulukko 3). Ketjun 1 markkinoijaa lukuun ottamatta kaikki muut ketjun toimijat kokivat ongelmaksi vähäisen ja/tai puuttuvan kuluttajille suunnatun tiedon. Kaupassa koettiin ongelmaksi myös tiedon saaminen tarjonnasta. Vähittäiskaupassa tämä ei koskenut tutkimuksen kohteena olleita ketjuja. Vaikka kaupalla on runsaasti myyntitietoa, sen hyödyntäminen luomumarkkinan kehittämisessä oli puutteellista. Euromääräinen ja tuotekohtainen myyntitieto ei ole mahdollistanut luomutuotteiden menestyksen tai menestymättömyyden analysointia.

Luomun tuotantoa ja valmistusta sääteleviin säädöksiin liittyvä tiedon tarve ja viiveet sen kulussa olivat ainoat selkeästi luomusta aiheutuvat tiedon tarpeet ja ongelmat. Toinen, usein luomuun yhdistettävä seikka on pienyrittäjyys. Pelkästään luomua valmistavat toimijat ovat usein pieniä yrityksiä, jotka tarjoavat 
tuotteittaan paikalliseen tai alueelliseen vähittäiskauppaan. Tieto näistä tavarantoimittajista on hajanainen eikä tavoita vähittäiskauppojen edustajia. Tukkukaupassa toivottiin tavarantoimittajien perustelevan tarkemmin, miksi he tarjoavat tuotetta luomuna.

\begin{tabular}{|c|c|c|c|c|}
\hline Viljelijät & Luomuvalmistaja & Markkinoija & Tukkukauppa & Vähittäiskauppa \\
\hline $\begin{array}{l}\text { Viranomaistiedon } \\
\text { puute, viiveet } \\
\text { Kuluttajille } \\
\text { suunnatun } \\
\text { informaation puute } \\
\text { Ostajilta tulevan } \\
\text { tiedon viiveet, } \\
\text { epäselvät vastuut, } \\
\text { ristiriidat }\end{array}$ & $\begin{array}{l}\text { Myyntitieto ei kulje } \\
\text { Puuttuva/vähäinen } \\
\text { kuluttajille suunnattu } \\
\text { informaatio } \\
\text { Kuluttajia koskevan } \\
\text { tiedon saanti }\end{array}$ & $\begin{array}{l}\text { Vähäinen } \\
\text { tiedonvaihto } \\
\text { kaupan } \\
\text { kanssa. } \\
\text { Sisäinen tiedon- } \\
\text { kulku. }\end{array}$ & \begin{tabular}{|l|} 
Kuluttajatietoa on, \\
leviämisessä ongelmia. \\
Liian vähän tietoa tarjonnasta \\
Liian vähän tietoa kuluttajille \\
Myyntitietoa on/on ollut \\
vaikea saada muuten kuin \\
tuotetasolla. \\
Valmistajien tulisi kertoa \\
tarkemmin, miksi he tarjoavat \\
tuotteen luomuna
\end{tabular} & $\begin{array}{l}\text { Luotettavaa, kattavaa } \\
\text { tietoa luomutuotteiden } \\
\text { tarjoajista ja } \\
\text { luomutuotteita } \\
\text { suosivista kuluttajista } \\
\text { ei ole. } \\
\text { Kuluttajille suunnatun } \\
\text { informaation puute }\end{array}$ \\
\hline
\end{tabular}

Taulukko 3. Luomutoimijoiden kokemat tai havaitut ongelmat tiedonkulussa

Tiedonkulun ja toimivuuden yhteyttä on kuvattu taulukossa 4. Yhdistelemällä ja luokittelemalla toimijoiden tiedontarpeita ja tiedonkulussa havaittuja ongelmia nousi esille tiedonkulkuun liittyviä toimenpiteitä, jotka parantaisivat tutkimuksen kohteena olleiden luomuketjun toimivuutta.

\begin{tabular}{|l|l|}
\hline Toimivuuden ulottuvuus & Miten tiedonkulun avulla toimivuutta voisi parantaa? \\
\hline Tuotteen kulku & $\begin{array}{l}\text { Tieto vaihto tukun varastomääristä valmistajan ja tukun kesken (ketju 2) } \\
\text { Toimituksiin liittyvien käytäntöjen selkeyttäminen (ketju 2) } \\
\text { Luotettava tiedonvaihto tavarantoimittajan toimituskyvystä } \\
\text { Tiedonvaihto hävikeistä ja hyllypuutteista }\end{array}$ \\
\hline $\begin{array}{l}\text { Kysynnän ja tarjonnan } \\
\text { kohtaaminen }\end{array}$ & $\begin{array}{l}\text { Kuluttajien toiveiden selvittäminen ja jakaminen ketjussa } \\
\text { Myyntitiedon jakaminen } \\
\text { Myyntitiedon laadun parantaminen (=analysointiedellytysten parantaminen) } \\
\text { Kuluttajille suunnatun informaation lisääminen } \\
\text { Pientoimittajien tarjontatiedon parantaminen } \\
\text { Markkinan kehittymistä koskevan tiedon tuottaminen ja jakaminen } \\
\text { Asiakasrekisterien hyödyntäminen luomua suosivien tavoittamisessa }\end{array}$ \\
\hline Toimijoiden yhteistyö & $\begin{array}{l}\text { Yritysten sisäisen tiedonvaihdon parantaminen } \\
\text { Ketjun läpinäkyvyyden lisääminen } \\
\text { Pitkän tähtäimen suunnitelmien jakaminen } \\
\text { Yhteisen tiedon lisääminen luomun mahdollisuuksista ja edellytyksistä }\end{array}$ \\
\hline
\end{tabular}

Taulukko 4. Ketjun tiedonkulun ja toimivuuden parantaminen

\section{Johtopäätökset}

Ketjun toimijoiden välinen vuorovaikutus ja tiedonkulku osoittivat, että tutkitut ketjut eivät toimi ketjuina. Tämä vaikeuttaa luomumarkkinan kehittymistä, koska luomutuotantoon vahvimmin sitoutuneet yritykset ovat pieniä yrityksiä, joiden voimavarat eivät yksin riitä markkinan analysointiin, tuotekehitykseen ja kuluttajille suunnattuun viestintään eikä heillä ole valtaa vaikuttaa ketjun muiden toimijoiden toimintaan. Vähäisen tiedonvaihdon syitä voivat olla elintarvikealalla perinteisesti vallinnut kulttuuri ja tiedon kokeminen strategisesti tärkeäksi (Coughlan et al. 2001, Fearne et al. 2001, Tarpila et al. 1999). Luomuketjujen osalta todennäköisesti luomun strategisella merkityksellä ja siihen suunnattavilla resursseilla on merkitystä.

Luomutiedon hallinta on ketjussa, erityisesti isoissa yrityksissä, heikkoa. Myymäläkohtaisen myyntitiedon analysointi tarjoaisi paljon tietoa luomumarkkinan analysointiin, mutta edellyttäisi kaupalta resurssien lisäämistä tiedon hallintaan tai halua luovuttaa tietoa ketjun muille toimijoille. Luomua koskeva kuluttaja- ja luomun lisäarvotieto ovat erittäin sirpaleisia ja osittain paikkaan, aikaan ja henkilöön sidottua ns. tacit- tietoa. Sen vuoksi tämän tiedon jakaminen on vaikeaa ketjumaisessa toimintamallissa, koska se edellyttäisi toimijoiden keskinäistä vuorovaikutusta (Hislop 2005).

Tutkimuksen perusteella ketjun toiminnan parantaminen tiedonkulun näkökulmasta edellyttäisi tiedon 
laadun parantamista, tiedonvaihdon lisäämistä ketjun toimijoiden kesken sekä ketjun toimijoiden vuorovaikutuksen laajenemista koskemaan myös muita kuin lähimpiä toimijoita.

\section{Kirjallisuus}

Alvarado, U.Y., Kotzab, H. 2001. Supply chain management: The integration of logistics in marketing. Industrial Marketing Management 30: 183

Baecke, E., Rogiers, G., De Cock, L., Van Huylenbroeck, G. 2002. The supply chain and conversion to organic farming in Belgium or the story of the egg and the chicken. Br Food J 104: 163-174

Bähr, M., Botschen, M., Laberentz, H., Naspetti, S., Thelen, E., Zanoli, R. 2004. The European Consumer and Organic Food. four: 190

Coughlan, A., Anderson, E., Stern, L., El-Ansary, A. 2001. Marketing channels. Prentice-Hall, New Jersey Fearne, A., Hughes, D., Duffy, R. 2001. Concepts of Collaboration - Supply Chain Management in a Global Food Industry. In: J. F. Eastham, L. Sharples and S. D. Ball (eds) Food and Drink Supply Chain Management Issues for the hospitality and retail sectors. Butterworth-Heinemann, pp 55-89

Finfood, 2004a. Organic Chain Barometer 1999-2004.

Finfood, 2004b. Organic Consumer Barometer 1998-2004.

Finne, S., Kokkonen, T.1998. Asiakaslähtöinen tarjontaketjun hallinta.

Franks, J. 2003. Current issues in marketing organic milk in the UK. British Food Journal 105: 350

Hamm, U., Gronefeld, F. 2004. The European Market for Organic Food: Revised and Updated Analysis. 165

Hislop, D. 2005. Knowledge management in organizations. 269

Lambert, D.M., Cooper, M.C., Pagh, J.D. 1998. Supply chain management: Implementation issues and research opportunities. International Journal of Logistics Management 9: 1

Marsden, T., Banks, J., Bristov, G. 2000. Food supply chain approaches: Exploring their role in rural development. Sociologia Ruralis 4: 424-438

Roosenbloom, B. 2004. Marketing channels: a management view.

Schmid, O., Sanders, J., Midmore, P. 2004. Organic Marketing Initiatives and Rural Development. 7: 150

Seppälä, T. 2003. Three Perspectives on Buyer-Supplier Relationships: A Relationship Assessment Model for Investigating Buyer-Supplier Relationships. In: Anonymous Inter-organisational Inter-functional and Intrafunctional Perspectives. Turku School of Economics and Business Administration, Turku

Tarpila, J., Lehtonen, J., Nyman, H., Saranen, J., Suomela, L., Tapionlinna, A., Yrjölä, H. 1999. ECR ja elintarviketeollisuuden toimitusketjun hallinta. 69: 107

Tushman, L.M., Nader, A. D. 1978. Information Processing as an Integrating Concept in Organizational Design. Academy of Management The Academy of Management Review 3: 613

Vorst van der, J. G.A. J. 2000. Effective Food Supply Chans, Generating, modelling and evaluating supply chain scenarios.

Wier, M., Calverley, C. 2002. Market potential for organic foods in Europe. British Food Journal 104: 45

Wycherley, I. 2002. Managing Relationships in the UK Organic Food Sector. Journal of Marketing Management 18: $673-692$ 